\title{
Comparative Study on Various Animal Manures and Process Parameters During Anaerobic Digestion of Food Waste
}

\author{
Tanuja Gharge, Vishwajit Chavan, Sayali Kodak and Sibi G* \\ Department of Biotechnology, Indian Academy Degree College-Autonomous, India
}

Submission: November 12, 2019; Published: January 24, 2020

*Corresponding author: Sibi G, Head of the Department, Department of Biotechnology, Indian Academy Degree College-Autonomous, Bengaluru, India

\begin{abstract}
Food waste management is a difficult task which leads to food safety issues as disposal of food waste is major problem. Some traditional methods are used for disposal of food waste but are inferior. The anaerobic digestion has significance approach in food waste management. This method generally involves hydrolysis, acidogenesis, acetogenesis and methanogenesis. Mainly thermophilic and mesophilic conditions are required for the anaerobic digestion process. For efficient process and stability in operational status, physiological parameters play immense role. The goal of given review is to produce biofuels by using various animal dungs for human welfare with respect to anaerobic digestion of food waste. This review covers the comparative study of different animal manures, bioreactors and process parameters involving in anaerobic digestion process.
\end{abstract}

Keywords: Anaerobic digestion; Thermophilic; Mesophilic; Bioreactors; Physiological parameters

\section{Introduction}

Over the entire globe, generation of enormous environmental, economical and social issues has been occurred due to food waste through food chain supply [1,2]. Food waste is generating increasingly from residential, commercial, institutional and industrial areas $[3,4]$. Food waste management is very challenging because of its high moisture content and simple deterioration $[5,6]$. Disposal of food waste is a major problem which is leading to food safety issues due to its incomplete management $[7,8]$. There are some traditional approaches for the disposal of food waste such as heat treatment, animal feed, incineration and land filling. But these methods are moderately good but less than excellent due to high moisture content, less calorific value and greater liability with respect to environmental impact $[4,9]$. Whereas, for proper food waste management there exists an effective approach called as anaerobic digestion. It has environmental significance that includes production of renewable energy, soil amendments, alcohol, volatile fatty acids and other valuable materials [9-12].

The process of anaerobic digestion involves four vital steps namely acidogenesis, acetogenesis, methanogenesis and hydrolysis [13]. Digestion of food waste at higher rate is often a challenging optimization problem as food waste is a heterogeneous substrate which includes lipids, carbohydrates, proteins and fibers that contains both easily fermentable and refractory complex organics. To overcome this problem, pretreatment of both inoculum and substrate and improvement of bioreactor configuration has been under focus by researchers [14-16]. The sources of bioaugmentation which involves the use of bacteria to speed up the digestion process are mainly found in animal manures as they contain microbes and enzymes in their digestive system which breakdown complex organic compounds in diet and microbial consortia is co-diversified with their host $[17,18]$. Distinctly, high rate of protein and lipid degrading microbes and enzymes are present in digestive track of carnivores whereas digestive track of herbivores contain enzymes and microbes which can breakdown the recalcitrant fibers and carbohydrates and omnivores involves both in their digestive system [19]. According to research study, the investigation of effect of bioaugmentation of various animal manures with respect to anaerobic digestion of food waste was done. Various animals involving tiger, giraffe, cow, llama, sloth bear, koala, were selected for the study and anaerobic sludge was used as inoculum [20]. Microbial consortia plays vital role in anaerobic digestion process in which thermophilic and mesophilic bacterial conditions are most widely used methods.

There are various parameters of the anaerobic digester which reflects the operational status of the process; these parameters involve $\mathrm{pH}$, gas production, volatile fatty acids, alkalinity. The study at a greater extent has been carried out to detect these process indicators mainly physiological parameters [21-26]. For 
improvement of stability and efficiency of anaerobic digester, control and monitoring the process of anaerobic digestion plays an immense role [21,24,27].

\section{Methodology}

A systematic search was carried out in PubMed, Scopus and Web of Sciences using a combination of Boolean operators. Peer reviewed papers in English on the Anaerobic digestion of food waste were retrieved and evaluated based on titles and abstracts. The retrieved papers were managed using Mendeley and the data were consolidated.

\section{Steps involved in the process}

The process of anaerobic digestion of food waste involves the microbial consortia which carry out the digestion in sequential stages. The steps involved are Acidogenesis, acetogenesis and methanogenesis. All the given processes are carried out in single stage batch reactor as all the waste is loaded simultaneously (Figure 1).

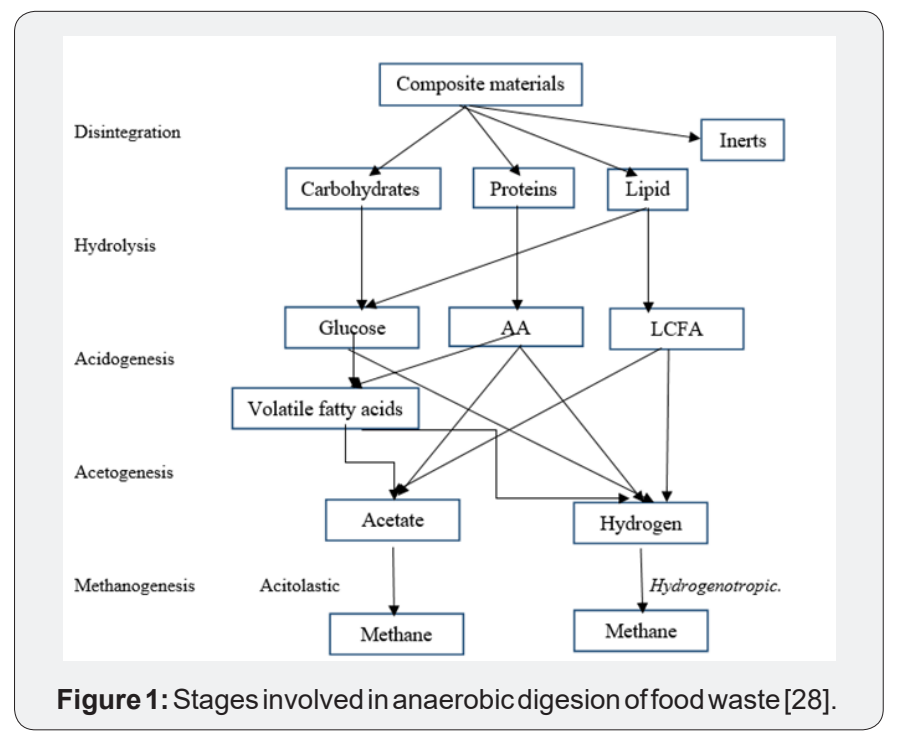

\section{Hydrolysis}

Table 1: Conversion of complex macromolecules duirng anaerobic digestion.

\begin{tabular}{|c|c|}
\hline Complex Macromolecules & Simpler Micromolecules \\
\hline Carbohydrates & Sugars \\
\hline Lipids & Long chain fatty acids \\
\hline Proteins & Amino acids \\
\hline
\end{tabular}

Hydrolysis process involves the breakdown of complex polymers or macro molecules into simpler, smaleer components. This process involves vital role of hydrolytic bacteria and also certain enzymes. In case of certain components, like lignin, cellulose and hemicellulose which are not easily accesible for degradation due to their complex structure,so in order to degrade them, certain hydrolytic enzymes are involved in order to make them easy for hydrolysis. Optimum temperature needed for the hydrolysis process is between $30-50^{\circ} \mathrm{C}$ and optimum pH is around 5-7 (Table 1).

\section{Acidogenesis}

This process also called as fermentation process and it involves acidogenic bacteria. After utilization of products of the hydrolysis, acidogenic bacteria produce intermediate volatile fatty acids and other products. Volatile fatty acids constitute a class of organic acids such as acetates, and larger organic acids such as propionate and butyrate also ethanol and lactate are also present. The condition of the anaerobic digester plays immense role with respect to the concentration of intermediate products during the process. This process is considered as one of the fastest process of anaerobic digestion of food waste as the regeneration time of acidogenic bacteria is fewer than $36 \mathrm{hrs}$. There is another process which is similar to the given one, named as Bokashi composting, a composting technique in which anaerobic digestion of food waste is carried out with the help of microbial community which gives highly acidic final product and is used as dry and liquid fertilizer.

\section{Acetogenesis}

This process involves the conversion of Volatile fatty acids and intermediates into acetate and hydrogen as a byproduct. Lipids follow another pathway of acetogenesis via acidogenesis and beta oxidation.

\section{Acidogenesis: Glycerol Acetate}

Beta oxidation: Long chain fatty acids Acetate

\section{Methanogenesis}

It is the last and finalized step in anaerobic digestion process. It involves the production of methane from intermediates produced in previous stages by methanogenic bacteria. The habitat of methanogens involves freshwater and marine water, sewage digesters, herbivores, wood and humus feeding insects etc. Methanogenic bacteria are classified into 4 groups. Each group requires a specific substrate in order to produce methane. Methanogenic bacteria class I requires acetate as a substrate and bacterial spp. is Methanosaeta. It produces methane from acetic acid and carbon dioxide as a byproduct. Class II uses hydrogen and formate as substrate and bacterial strains are Methanobrevibater spp. and Methanogenium spp. In this process, carbon dioxide and water produce methane and $\mathrm{H} 2 \mathrm{O}$ as a byproduct. Class III involves Methylated compounds as a substrate and the microbes involved are Methanolobus spp. and Methanococcus spp. The first one spp. converts methanol into methane and $\mathrm{CO} 2$ and $\mathrm{H} 2 \mathrm{O}$ as a byproducts. Also, Methanococcus spp. converts methylamine and $\mathrm{H} 2 \mathrm{O}$ into methane and $\mathrm{CO} 2$ and ammonia as byproducts. Class IV involves acetate, hydrogen and methylated compounds and the bacterial spp. is Metahanosarcina. It involves combinations of all the previous reactions of methane production (Table 2).

Dung from various animals was taken to which food waste was added as substrate. Anaerobic sludge was used as inoculum 
which was added to it. Pretreatment involved the dislodging of undesirable matter manually and homogenization of remaining dung in which addition of tap water to it was done to match their volatile solid content with volatile solid of anaerobic sludge. Then the whole mixture is sieved through mesh no. $20(0.85 \mathrm{~mm})$ to withdraw any undesirable debris or particles [20] (Table $3 \& 4$ ).

Table 2: Types of bioreactors with respect to substrate in anaerobic digestion process.

\begin{tabular}{|c|c|c|c|}
\hline Bioreactor Type & Substrate & Co-substrate & Reference \\
\hline $\begin{array}{c}\text { One and two stage anaerobic hydrogen and } \\
\text { methane production reactor }\end{array}$ & Cow dung & Olive mill waste & {$[28,29]$} \\
\hline Anaerobic sequencing batch bioreactor & Fruit and vegetable waste (Domestic) & Abbettoir waste water & {$[30]$} \\
\hline Full scale anaerobic digester & Industrial food waste & Industrial organic waste water & {$[24]$} \\
\hline Up flow anaerobic solid-state bioreactor & Mixture of maize silage and straw & Renewable raw material & {$[31]$} \\
\hline $\begin{array}{c}\text { Two stage anaerobic hydrogen and methane } \\
\text { production reactor }\end{array}$ & Organic waste & Animal residues & {$[29]$} \\
\hline Self-mixing anaerobic digester & Poultry manure & Agricultural fertilizer & {$[32]$} \\
\hline Up flow anaerobic solid-state bioreactor & Beet leaf silage & Renewable raw material & {$[31]$} \\
\hline
\end{tabular}

Table 3: Comparative study of various types of animal manure involving in anaerobic digestion of food waste [20].

\begin{tabular}{|c|c|}
\hline Animal Manure & Biomethane Production \\
\hline Herbivores & $156.05 \pm 11.25 \mathrm{ml} \mathrm{CH} 4 / \mathrm{g}$ \\
\hline Giraffe & $121.74 \pm 0.24 \mathrm{ml} \mathrm{CH} 4 / \mathrm{g}$ \\
\hline Koala & $112.50 \mathrm{ml} \mathrm{CH} 4 / \mathrm{g}$ \\
\hline Cow & $9.72 \mathrm{ml} \mathrm{CH} 4 / \mathrm{g}$ \\
\hline Lama & $128.25 \pm 22.50 \mathrm{ml} \mathrm{CH} 4 / \mathrm{g}$ \\
\hline Omnivores & \\
\hline Sloth bear & $89.20( \pm 2.73) \mathrm{ml} \mathrm{CH} 4 / \mathrm{g}$ \\
\hline Carnivores & \\
\hline Tiger & \\
\hline &
\end{tabular}

Table 4: Process parameters of anaerobic digester of food waste.

\begin{tabular}{|c|c|c|}
\hline Parameters & Concentration & Reference \\
\hline Volatile fatty acids & $<1500 \mathrm{mg} / \mathrm{l}$ & {$[29]$} \\
\hline $\begin{array}{c}\text { Intermediate alkalinity / } \\
\text { Partial alkalinity }\end{array}$ & $\leq 0.3$ & \\
\hline Volatile fatty acids & $2500-3500 \mathrm{mg} / \mathrm{l}$ & {$[30]$} \\
\hline $\begin{array}{c}\text { Intermediate alkalinity } \\
\text { Partial alkalinity }\end{array}$ & $13000-15000 \mathrm{mg} / \mathrm{l}$ & {$[24]$} \\
\hline $\begin{array}{c}\text { Intermediate alkalinity / } \\
\text { alkalinity }\end{array}$ & 0.35 & \\
\hline $\begin{array}{c}\text { Bicarbonate alkalinity / Total } \\
\text { alkalinity }\end{array}$ & 0.8 & \\
\hline
\end{tabular}

\section{Conditions required in anaerobic digestion process}

The study done by Chao et al. [31] involves the effect of organic loading rate and anaerobic digestion of food waste under thermophilic and mesophilic conditions. The obtained results of anaerobic digestion showed that the process majorly involves the temperature, organic loading rate (ORL), in order to produce biogas. Food waste was collected from a canteen of an institute which was then treated to remove the impurities manually which again was smashed to $2-5 \mathrm{~mm}$ with a pulverizer. 12 laboratory scale bottles of $500 \mathrm{~mL}$ were used as a digester with $400 \mathrm{~mL}$ working volume of which 6 were kept in thermophilic condition and 6 were kept in mesophilic condition for 23 days prior to production of biogas. Biogas ( $\mathrm{CH} 4$ and $\mathrm{CO} 2$ ) compositions were measured by a gas chromatograph [31]. The Organic loading rate provided was $2.5 \mathrm{~g}$ of volatile solids (VS)/L/day and $1.5 \mathrm{~g}$ of volatile solids (VS)/L/day for thermophilic and mesophilic respectively. Results obtained says that under thermophilic condition the methane yield was $33-49 \%$ higher than that of the mesophilic condition it also suggests that the thermophilic condition is more efficient for anaerobic digestion. The other work done by Guo et al. [32] involves the use of same mesophilic and thermophilic conditions. In this work the use of mesophilic and thermophilic reactor was done in order to study the anaerobic digestion of the food waste. In this study the comparison was based on the response of microbial population to increasing Organic loading rate. Both the reactors were provided with same range of organic loading rate of 1.0 to 2.5g VS L-1 d-1 at which mesophilic reactor showed more stable performance than the thermophilic reactor in terms of methane yield.

Tojo et al. [33] worked on the anaerobic digestion of food waste mixed with cardboard mixtures which was subjected to batch digestion using three different inocula. They mainly focused on the archeal community of the inocula. The test started with inocula rich in Methanosarcina which brought about efficient methane production Volatile fatty acids accumulated in the reactors where inocula initially were poor in these archaea and no methane was produced. Also, the higher substrate load was tolerated by the Methanosarcina they were the dominant methanogens in the digestate from experiment that produced methane. So, the conclusion was the initial composition is important in order to obtain stable anaerobic digestion. In one more study, usefulness of two step processes using non-airtight fermentation of potato peels with dairy manure followed by struvite precipitation was 
done. The non-airtight fermentation for 6 days in the vessel lead to acidification and hydrolysis and which resulted in decrease in $\mathrm{pH}$ upto 6.4 also the ratio of reactive phosphorous to total phosphorous increased from 49.6 to $93.7 \%$ by adjusting the $\mathrm{pH}$ to 8.0 and 9.5 the struvite formation was successfully induced. The struvite formation was analysed for scanning electron microscopy as well as energy dispersive spectrometry (SEM-EDS) the results obtained shoed that there should be appearance of both struvite and calcium phosphate. The $\mathrm{pH} 8$ contains about $75 \%$ struvite and pH 9.5 contains $90 \%$ of the same [34].

In another study [35], garden waste and food wastes were fermented together in two step process hyperthermophilic dark-fermentation and mesophilic anaerobic digestion coupled together. In first stage the matter was digested using pure culture of Caldicellulosiruptor saccharolyticus as inoculum for production of biohydrogen. Food waste concentrations in volatile solids above 2.9g L-1 caused a lag phase of 5 days on biohydrogen production there was no lag phase for garden waste concentrations up to 25.6g L-1. The co-fermentation experiments led to the highest hydrogen yield up to $46 \pm 1 \mathrm{~L} \mathrm{kg-1}$ for Garden waste: Food waste $90: 10 \%(w / w)$. During the second stage, a biomethane yield of $682 \pm 14 \mathrm{~L} \mathrm{~kg}-1$ was obtained using the end products of Garden waste: Food waste 90:10\% co-fermentation. According to Treu et al. [36], when a continuous stirred tank reactors fed with cheese whey at different operational conditions such as themophilic $\left(54^{\circ} \mathrm{C}\right)$ and mesophilic $\left(37^{\circ} \mathrm{C}\right)$ to enquire productivity of methane production at lab scale. The conclusion was that when whey is mono digested it was feasible at mesophilic condition which in case of thermophilic condition leads to frequent acidification. When the cheese whey was co-digested with cattle manure it maintained the $\mathrm{pH}$ levels higher than 7.0 and therefore there was a stable rate of methane production without exploration of volatile fatty acids. The increase in methane production was achieved by dispersion of hydrogen in situ at mesophilic and thermophilic conditions. Hydrogenotrophic methanogens were the dominant archaea during the whole experiment.

According to Borowski et al. [37] the food waste was digested an aerobically with slaughterhouse waste and municipal sewage sludge waste. The digestion was carried out in 3-dm3 laboratory reactors as well as in $50 \mathrm{dm} 3$ reactors which were operated in semi continuous condition. The combination of food waste with slaughterhouse waste gave more methane yield. $63 \mathrm{~m} 3 \mathrm{CH} 4 /$ $\mathrm{kg}$ Volatile solidfed when was digested in laboratory digester for around 30 days. Whereas the digestion of food waste with municipal sewage sludge waste gave methane yield of $0.46 \mathrm{~m} 3$ $\mathrm{CH} 4 / \mathrm{kg}$ Volatile solidfed. The conditioning tests with the digestates from reactor experiments revealed the highest efficiency of inorganic coagulants among all investigated chemicals, which applied in a dose of $10 \mathrm{~g} / \mathrm{kg}$ allowed to reduce capillary suction time of the digestate below 20s. The conditioning of combination of coagulants with bentonite further did not shown any reduction in Capillary suction time value but it showed the improvement in the quality of the digestate supernatant. In other words, the suspended solids concentration, chemical oxygen demand and the metals in the supernatant faced the reduction. After production of edible mushrooms, the residue is remained called as spent mushroom substrate which occurs in huge amount which can be digested for production of biogas in mesophilic condition in an anaerobic condition. The digestion of spent mushroom substrate in thermophilic anaerobic condition was inspected and also interconnected microbial population structure changes were taken under examination [38]. This digestion was carried out for 12 days and it gave methane yield of $177.69 \mathrm{~mL} / \mathrm{g}$ volatile solid (VS). Hydrolytic activities during the process of digestion increased the methane production 4 days to 6 days. The most common archaea were Crenarchaeota. Both Methanothermobacter and Methanobacterium were the most commanding general of the archaea but there was sharp decline in number with time.

\section{Conclusion}

The instability in performance of anaerobic digester is a major problem in the process of digestion. To overcome this problem, microbial management, process control and monitoring are useful methods. Also, improvement in bioreactors plays vital role and is efficient. Anaerobic digestion using animal manure is more efficient than traditional approaches. In the given review, comparative study of process has done by using various animal dungs which are having the ability to stimulate biomethane production from food waste. Among these, giraffe dung showed high yield of biomethane. Thermophilic conditions showed greater potential than mesophilic conditions for anaerobic digestion process. Physicochemical parameters mentioned in the given review are efficient to achieve stability and improved performance.

\section{References}

1. Browne J, Murphy J (2013) Assessment of the resource associated with biomethane from food waste. Applied Energy 104: 170-177.

2. Papargyropoulou E, Lozano R, Steinberger JK, Wright N, Ujang Z (2014) The food waste hierarchy as a framework for the management of food surplus and food waste. Journal of Cleaner Production 76: 106-115.

3. Dai X, Duan N, Dong B, Dai L (2013) High-solids anaerobic co-digestion of sewage sludge and food waste in comparison with mono digestions: stability and performance. Waste Management 33(2): 308-316.

4. Girotto F, Alibardi L, Cossu R (2015) Food waste generation and industrial uses: a review. Waste Management 45: 32-41.

5. Zhang L, Jahng D (2012) Long-term anaerobic digestion of food waste stabilized by trace elements. Waste Management 32(8): 1509-1515.

6. Zhang L, Lee YW, Jahng D (2011) Anaerobic co-digestion of food waste and piggery wastewater: Focusing on the role of trace elements. Bioresource Technology 102(8): 5048-5059.

7. Li L, He Q Ma Y, Wang X, Peng X (2015) Dynamics of microbial community in a mesophilic anaerobic digester treating food waste: relationship between community structure and process stability. Bioresource Technology 189: 113-120. 
8. Thi NBD, Kumar G, Lin CY (2015) An overview of food waste management in developing countries: Current status and future perspective. Journal of Environmental Management 157: 220-229.

9. Han B, Sivaramakrishnan P, Lin CJ, Neve IAA, He J, et al. (2017) Microbial Genetic Composition Tunes Host Longevity. Cell 169(7): 1249-1262.

10. Capson TG, Trably E, Rouez M, Crest M, Steyer JP, et al. (2017) Dry anaerobic digestion of food waste and cardboard at different substrate loads, solid contents and co-digestion proportions. Bioresource Technology 233: 166-175.

11. Li L, Lyu X, Hou C, Takenaka N, Nguyen HQ, et al. (2015) Widespread Rearrangement of 3D Chromatin Organization Underlies PolycombMediated Stress-Induced Silencing. Molecular Cell 58(2): 216-231.

12. Zhang L, Liu N, Ma X, Jiang L (2012) The transcriptional control machinery as well as the cell wall integrity and its regulation are involved in the detoxification of the organic solvent dimethyl sulfoxide in Saccharomyces cerevisiae. FEMS Yeast Research 13(2): 200-218.

13. Leung DYC. Wang J (2016) An overview on biogas generation from anaerobic digestion of food waste. International Journal of Green Energy 13(2): 119-131.

14. Esposito G, Ariunbaatar J, Panico A, Pirozzi F, Lens PNL (2014) Pretreatment methods to enhance anaerobic digestion of organic solid waste. Applied Energy 123: 143-156.

15. Kim M, Gomec CY, Ahn Y, Speece RE (2003) Hydrolysis and acidogenesis of particulate organic material in mesophilic and thermophilic anaerobic digestion. Environmental Technology 24(9): 1183-1190.

16. Mao C, Feng Y, Wang X, Ren G (2015) Review on research achievements of biogas from anaerobic digestion. Renewable and Sustainable Energy Reviews 45: 540-555.

17. Bayane A, Guiot SR (2010) Animal digestive strategies versus anaerobic digestion bioprocesses for biogas production from lignocellulosic biomass. Reviews in Environmental Science and Biotechnology 10: 43-62.

18. Godon JJ, Arcemisbehere L, Escudie R, Harmand J, Miambi E, et al. (2013) Overview of the oldest existing set of substrate-optimized anaerobic processes: Digestive Tracts. BioEnergy Research 6(3): 10631081.

19. Hume ID (2002) Digestive strategies of mammals. Acta Zool Sinica 48(1): 1-19.

20. Ariunbaatar J, Ozcan O, Bair R, Esposito G, Ball R, et al. (2017) Bioaugmentation of the anaerobic digestion of food waste by dungs of herbivore, carnivore, and omnivore zoo animals. Environmental Technology 39(4): 516-526.

21. Boe K, Batstone DJ, Steyer JP, Angelidaki I (2010) State indicators for monitoring the anaerobic digestion process. Water Research 44: 59735980 .

22. Kleyböcker A, Liebrich M, Verstraete W, Kraume M, Würdemann H (2012) Early warning indicators for process failure due to organic overloading by rapeseed oil in one-stage continuously stirred tank reactor, sewage sludge and waste digesters. Bioresource Technology 123: $534-541$

23. Kroeker EJ, Lapp HM (1979) Anaerobic treatment process stability. Journal of Water Pollution Control Federation 51(4): 718-727.

24. Li L, He Q Wei Y, He Q, Peng X (2014) Early warning indicators for monitoring the process failure of anaerobic digestion system of food waste. Bioresource Technology 171: 491-494.
25. Lv Z, Hu M, Harms H, Richnow HH, Liebetrau J, et al. (2014) Stable isotope composition of biogas allows early warning of complete process failure as a result of ammonia inhibition in anaerobic digesters. Bioresource Technology 167: 251-259.

26. Polag D, May T, Muller L, Konig H, Jacobi F, et al. (2015) Online monitoring of stable carbon isotopes of methane in anaerobic digestion as a new tool for early warning of process instability. Bioresource Technology 197: 161-170.

27. Molina F, Castellano M, Garcia C, Roca E, Lema JM (2009) Selection of variables for on-line monitoring, diagnosis, and control of anaerobic digestion processes. Water Science Technology 60(3): 615-622.

28. Morales-Polo C, del Mar Cledera-Castro M, Moratilla Soria BY (2018) Reviewing the anaerobic digestion of food waste: from waste generation and anaerobic process to its perspectives. Applied Sciences 8(10): 1804.

29. Bernard O, Polit M, Hadj-Sadok Z, Pengov M, Dochain D, et al. (2001) Advanced monitoring and control of anaerobic wastewater treatment plants: software sensors and controllers for an anaerobic digester. Water Science Technology 43(7): 175-182.

30. Martin-Gonzalez L, Font X, Vicent T (2013) Alkalinity ratios to identify process imbalances in anaerobic digesters treating source-sorted organic fraction of municipal wastes. Biochemical Engineering Journal 76: $1-5$

31. Chao L, Wen W, Naveed A, Zonghu M, Guangqing L, et al. (2017) Effect of organic loading rate on anaerobic digestion of food waste under mesophilic and thermophilic conditions. Energy fuels 31(3): 29762984.

32.Xiaohui G, Cheng W, Faqian S, Weijing Z, Weixiang W (2014) A comparison of microbial characteristics between the thermophilic and mesophilic anaerobic digesters exposed to elevated food waste loadings. Bioresource Technology 120: 420-428.

33. Capson-Tojo G, Trably E, Rouez M, Crest M, Bernet N, et al. (2018) Methanosarcina plays a main role during methanogenesis of highsolids food waste and cardboard. Waste Management 76: 423-430.

34. Wang L, Chen L, Wu SX, Krosuri A (2019) Non-airtight fermentation of dairy manure with waste potato peels and subsequent phosphorus recovery via struvite precipitation. Applied Biochemistry and Biotechnology.

35. Abreu AA, Tavares F, Alves MM, Cavaleiro AJ, Pereira MA (2019) Garden and food waste co-fermentation for biohydrogen and biomethane production in a two-step hyperthermophilic-mesophilic process. Bioresource Technology 278: 180-186.

36. Treu L, Tsapekos P, Peprah M, Campanaro S, Giacomini A, et al. (2019) Microbial profiling during anaerobic digestion of cheese whey in reactors operated at different conditions. Bioresource Technology 275: 375-385.

37. Borowski S, Boniecki P, Kubacki P, Czyżowska A (2018) Food waste co-digestion with slaughterhouse waste and sewage sludge: Digestate conditioning and supernatant quality. Waste Management 74: 158167.

38. Xiao Z, Lin M, Fan J, Chen Y, Zhao C, et al. (2017) Anaerobic digestion of spent mushroom substrate under thermophilic conditions: performance and microbial community analysis. Applied Microbiology and Biotechnology 102(1): 499-507. 


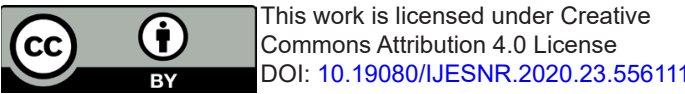

Your next submission with Juniper Publishers will reach you the below assets

- Quality Editorial service

- Swift Peer Review

- Reprints availability

- E-prints Service

- Manuscript Podcast for convenient understanding

- Global attainment for your research

- Manuscript accessibility in different formats ( Pdf, E-pub, Full Text, Audio)

- Unceasing customer service

Track the below URL for one-step submission https://juniperpublishers.com/online-submission.php 